\title{
2018 van start
}

\author{
Peter F. A. Mulders ${ }^{1}$
}

Het jaar 2018 is weer goed begonnen en, als klap op de vuurpijl, ligt nu ook nog het eerste nummer van het Tijdschrift voor Urologie op de deurmat. Namens de gehele redactie een goed en voorspoedig urologisch jaar toegewenst met veel en intens leesplezier. Dat begint met een stuk over seksuele en erectiele disfunctie in de breedste zin van het woord, als implicatie van prostaatkankerbehandeling. Dit onderzoek, dat is uitgevoerd door het Leids Universitair Medisch Centrum, maakt duidelijk dat ook de partners bij de helft van de koppels daar veel problemen mee hebben. Een onderwerp dat dus in de spreekkamer aan bod moet komen om de kwaliteit van onze prostaatbehandelingen te verhogen.

Vervolgens verwijzen Andre Vis et al. uit het NKI naar alle issues rondom het gebruik van de PSMA-PET-scan bij de diagnostische work-up van het prostaatcarcinoom. Zij besluiten hun artikel met een advies over validatie in prospectieve studies. Deze validatie gaat er wel komen, maar ondertussen wordt dit onderzoek al dusdanig geïmplementeerd dat het waarschijnlijk alleen nog om de finetuning ervan zal gaan. PSMA-PET-imaging zal niet meer weg te denken zijn.

Ten slotte een casus die zich voordeed in het Antonius Ziekenhuis, over een patiënt met peniele partiële trombose; een zeldzaam fenomeen, maar toch hebben de auteurs van deze casus een duidelijk diagnostisch en therapeutisch advies.

Uit dit nummer van het tijdschrift blijkt enerzijds dat er veel variatie is in de aangeboden artikelen, maar anderzijds dat prostaatkanker toch een van onze meest beschreven tumorsoorten is, en waarschijnlijk zal blijven.

Veel leesplezier.

Open Access This article is distributed under the terms of the Creative Commons Attribution 4.0 International License (http:// creativecommons.org/licenses/by/4.0/), which permits unrestricted use, distribution, and reproduction in any medium, provided you give appropriate credit to the original author(s) and the source, provide a link to the Creative Commons license, and indicate if changes were made.

Prof. dr. Peter F.A. Mulders uroloog
Prof. dr. Peter F. A. Mulders

peter.mulders@radboudumc.nl

1 Afdeling Urologie, Radboud Universitair Medisch Centrum Nijmegen, Nijmegen, Nederland 